\title{
Pesan Dakwah dalam Buku Gapleh
}

\author{
Agus Saepulloh $^{1 *}$, Tjetjep Fachruddin ${ }^{1}$, Yuliani $^{2}$ \\ ${ }^{1}$ Jurusan Komunikasi dan Penyiaran Islam, Fakultas Dakwah dan Komunikasi, UIN Sunan \\ Gunung Djati, Bandung \\ ${ }^{2}$ Jurusan Manajemen Dakwah, Fakultas Dakwah dan Komunikasi, UIN Sunan Gunung Djati, \\ Bandung \\ *Email : agussaepulloh195@gmail.com
}

\begin{abstract}
ABSTRAK
Penelitian ini bertujuan untuk mengetahui dan menganalisis isi pesan dakwah pada buku Gapleh "Gaul Tapi Soleh". Secara rinci tujuan penelitian ini untuk mengetahui pesan dakwah dari segi akidah, akhlak, dan syariah yang terkandung dalam buku Gapleh karya Ustad Evie Effendie. Metode penelitian yang digunakan adalah metode kualitatif, didasarkan pada asumsi teori analisis isi yang dikembangkan oleh Harold D. Lasswell, untuk memperoleh keterangan dari komunikasi yang disampaikan dalam buku, dan teknik pengumpulan data mengguanakan studi dokumentasi, wawancara dan pengamatan pada buku Gapleh karya Ustad Evie Effendie. Hasil penelitian ini menunjukkan bahwa pesan dakwah pada buku Gapleh karya Ustad Evie Effendie, terdapat kategori pesan dakwah seperti yang telah dipilah yaitu menjadi tiga bagian pesan, diantaranya (a) akidah meliputi nilai-nilai keimanan seseorang muslim. (b) syariah meliputi ibadah yang harus dilaksanakan oleh seorang muslim, dan (c) akhlak meliputi nilai-nilai mengenai pembahasan tentang cara perilaku seseorang terhadap Allah, manusia dan lingkungannya.
\end{abstract}

Kata Kunci : pesan dakwah; buku gapleh; Ustad Evie Effendie.

\section{ABSTRACT}

This study tried to study and analyze the contents of the da'wah message in the book "Gapul But Soleh". In detail the purpose of this study is to find out the message of preaching in terms of aqeedah, morals, and sharia contained in the book. Gapleh by Ustadh Evie Effendie. The research method used is a qualitative method, based on the assumption of content analysis theory developed by Harold D. Lasswell, to obtain information from the communication conveyed in the book, and data collection techniques using documentation studies, interviews and briefings on the book Gapleh by Ustad Evie Effendie. The results of this study show da'wah messages on Gapleh's book. by Ustadh Evie Effendie, including the category of da'wah 
messages as they have been divided into three parts of the message, so that (a) the aqid Share the values of one's Muslim faith. (b) shari'a about worship that must be carried out by a Muslim, and (c) adding values about the discussion of how to make one's relationship with God, bumans and their environment.

Keywords : preaching message; gapleh book; Ustad Evie Effendie.

\section{PENDAHULUAN}

Dakwah merupakan ajakan kepada manusia mengenai pesan atau ajaran Islam agar senantiasa berbuat baik atau lebih baik untuk mencapai kebahagian didunia atau di akhirat, serta mengandung ide mengenai progresivitas. Sehingga dalam dakwah terdapat suatu ide dinamis, sesuatu yang terus tumbuh dan berkembang sesuai dengan tuntunan ruang dan waktu. dalam prakteknya dakwah memiliki kegiatan untuk menyalurkan, memberikan, mengiformasikan, dan mengajarkan nilai-nilai agama yang memiliki arti penting serta berperan langsung dalam membentukan persepsi umat tentang berbagai nilai kehidupan.

Dakwah memiliki makna dan arti yang begitu penting bagi kehidupan manusia. Oleh sebab itu, cukup beralasan jika dibutuhkan pemaknaan dan pemahaman baru terhadap dakwah, apalagi jika didasarkan pada kenyataan masih banyaknya pemahaman masyarakat mengenai dakwah yang mengidentikannya hanya sebatas tabligh atau khithabah.

Dakwah merupakan sentuhan-sentuhan psikologis dan sosiologis dengan realitas yang ada, sehinggal dakwah mampu memberikan dasar filosofis, arah, dorongan dan pedoman perubahan masyarakat sampai terwujudnya masyarakat yang islami, yakni berupa individu-individu yang memahami dan melaksanakan agama, keluarga yang sakinah, mawadah warohmah, masyarakat yang martabat, serta ujungnya adalah negara yang toyyibah (Aripudin, 2014:123).

Dakwah sekarang dipahami bukan hanya proses penyampaian pesan Islam dalam bentuk ceramah, Khutbah di podium atau mimbar saja, yang biasa dilakukan para penceramah atau mubaligh. Akan tetapi, dakwah merupakan berbagai aktivitas keislaman yang memberikan dorongan, percontohan, dan penyadaran baik berupa aktivitas lisan ataupun tulisan (ahsanuqaulan) maupun aktivitas badan atau perbuatan nyata (ahsanuamalan) dalam rangka merealisasikan nilai-nilai ajaran Islam yang dilaksanakan oleh seluruh umat Islam sesuai dengan kedudukan dan profesinya masing-masing, untuk mewujudkan kehidupan individu dan kelompok yang salam, hasanah, thayyibah (adil, makmur, sejahtera), dan memperoleh ridha Allah.

Dengan begitu dakwah akan lebih terarah apabila didalam materi dakwah tersebut mengandung sentuhan-sentuhan psikologis dan sosiologis dengan realitas yang ada. Model dakwah seperti ini telah dilakukan oleh Ustadz Evie Effendie, dimana materi-materi dakwah yang digunakan oleh beliau 
menyesuaikan dengan kondisi anak muda zaman sekarang.

Dakwah melalui tulisan telah banyak dilakukan salah satunya oleh penulis contohnya adalah Felix Siaw dimana dia banyak menulis tentang bagaimana cara berdakwah lewat tulisan motivasi islami sehingga banyak penulis buku dakwah yang lebih menegaskan bagaimana proses berhijrah.

Buku juga menjadi salah satu media yang digunakan oleh beliau dalam menyebarkan dakwah. Salah satunya adalah buku yang berjudul Gapleh (Gaul Tapi Soleh). Dalam buku tersebut membahas berbagai macam cara untuk berhijrah khususnya pada kalangan anak muda yang di tulis oleh Ustadz Evie Effendie.

Pengertian dakwah bil qalam yaitu mengajak manusia dengan cara bijaksana kepada jalan yang benar seperti yang diperintahkan oleh Allah Swt. lewat seni tulisan. Dakwah bil Qalam yang mengutip dari Tasfir Departemen Agama RI menyebutkan adalah mengajak manusia dengan cara bijaksana kepada jalan yang benar menurut perintah Allah Swt. melalui seni tulisan. (Kasman, 2004:120)

Zaman sekarang banyak pemuda yang dirinya berada dalam keyakinan sebagai muslim namun tingkah laku sehari-harinya masih banyak yang tidak sesuai atau yang seharusnya dilakukan sebagai pemuda muslim. Sehingga banyak Ustadz yang bermuculan dengan menggunakan metode penyebaran dakwah dengan gaya anak muda, sehingga memudahkan para Ustadz tersebut untuk menyampaikan dakwah islam kepada para pemuda.

Salah satu media yang digunakan untuk menyebarkan dakwah islam adalah lewat media tulisan, salah satunya adalah buku. Berdakwah lewat media tulisan (buku) telah banyak digunakan oleh para Da'i, agar memudahkan Da'i tersebut dalam menyebarkan dakwah.

Banyaknya anak muda pada zaman sekarang yang jarang mengikuti kajian atau kegiatan islami, membuat para Ustadz berfikir untuk menggunakan media dakwah yang lebih effektif agar dakwah islam tersampaikan. Salah satu media yang baik digunakan untuk berdakwah adalah melalui media elektronik atau media sosial. Banyaknya orang-orang kreatif yang membuat konten-konten dakwah yang menarik perhatian.

Buku yang telah terbit pada tahun 2018 ini, memiliki keunikan dimana dakwah disampaikan dengan kata-kata yang praktif dan ringan dengan bahasa yang mudah dipahami dan kata-kata gaul yang familiar. Sehingga memudahkan pembaca buku tersebut mudah ingat dan memahami isi dari buku tersebut.

Banyak singkat-singkatan kata unik yang digunakan Ustadz Evie Effendie untuk menyampaikan pesan dakwah kepada para pembaca bukunya. Kata-kata singkatan itu merupakan salah satu metode dakwah yang digunakan dalam bukunya beliau.

Dalam pembahasan mengenai analisis isi pesan dakwah sudah banyak yang meneliti, akan tetapi analisi pesan dakwah dalam bahasa gaul masih sangat 
jarang digunakan.

Seperti peneliatian sebelumnya yang dilakukan oleh Wenny Atikasari pada tahun 2016 yang berjudul Analisis Isi Pesan Dakwah Anak Kecil Yang Mengubah Dunia Karya M. Iqbal Dawami. Dalam penelitiannya yang memberikan pesan dakwah mengenai imbauan motivasi, imbauan emosional, imbauan takut. Kemudian penelitian yang dilakukan oleh Ais Muflihah pada tahun 2014 yang berjudul Analisis Isi Pesan Dakwah Dalam Buku Laa Tahzan For Hijabers Karya Asma Nadia, Helvy Tiana Rosa, Dkk yang memberikan pesan dakwah mengenai syari'ah, akhlak, akidah dan pesan dakwah yang paling dominan dalam buku Laa Tahzan For Hijabers karya Asma Nadia, Helvy Tiana Rosa, dkk. Dan penelitian yang dilakukan oleh Muhamad Ripai pada tahun 2016 yang berjudul Dakwah Novel Bait Surau (Studi Analisis Isi Pesan Dakwah dalam Novel Bait Surau) yang membahas mengenai bentuk imbauan dan kategore pesan dakwah pada Novel Bait Surau.

Sedangkan pembahasan dalam penelitian ini merujuk pada buku Gapleh dengan mengkaji bagian analisis isi yang terkandung dalam buku Gapleh "Gaul Tapi Sholeh" karya Ustadz Evie Effendie. ditinjau dari segi akidah, segi syari'ah, dan segi akhlak

Dengan demikian maka penulis sangat tertarik untuk melakukan penelian terhadap buku Gapleh "Gaul Tapi Soleb” karya Ustadz Evie Effendie, dengan judul penelitian "Pesan Dakwah dalam Buku Gapleh (Studi Analisis Isi Pesan Dakwah dalam Buku GAPLEH karya Ustadz Evie Effendie)’”.

\section{LANDASAN TEORITIS}

Dakwah sekarang dipahami bukan hanya proses penyampaian pesan Islam dalam bentuk ceramah, Khutbah di podium atau mimbar saja, yang biasa dilakukan para penceramah atau mubaligh. Akan tetapi, dakwah merupakan berbagai aktivitas keislaman yang memberikan dorongan, percontohan, dan penyadaran baik berupa aktivitas lisan ataupun tulisan (ahsanuqaulan) maupun aktivitas badan atau perbuatan nyata.

Dakwah dapat dikatakan sebagai proses penyampaian pesan-pesan tertentu berupa ajakan, seruan, undangan untuk mengikuti pesan tersebut atau menyeru dengan tujuan untuk mendorong seseorang untuk melakukan cita-cita tertentu" (Aliyudin, 2014:4).

Dakwah menekankan kepada sistem kebaikan, kebenaran, petunjuk, ajaran, menganalisis kebatilan dengan berbagai macam pendekatan, metode dan media agar mad'u mendapatkan keselamatan dan kebahagiaan hidup di dunia dan akhirat. Seperti apa yang dikatakan Al Mursyid bahwa dakwah merupakan sistem dalam menegakan penjelasan kebenaran, kebajikan, petunjuk ajaran, memerintahkan perbuatan ma'ruf mendapatkan keselamatan di dunia dan 
akhirat hakekat dakwah adalah menyeru umat manusia. seruan tersebut tidak bisa berjalan dengan maksimal apabila tidak diimbangi dengan komponenkomponen yang terdapat dalam dakwah (Aliyudin, 2009:9).

Proses kegiatan dakwah tidak terlepas dari komponen-komponen yang menunjang kelancaran kegiatan tersebut. Adapun bagian-bagian dari unsurunsur dakwah itu diantaranya: 1) Da’, merupakan sebutan untuk orang yang menjadi perilaku dakwah. Da'i adalah orang yang mengajak kepada orang lain baik secara langsung, melalui tulisan, lisan atau perbuatan untuk mengamalkan ajaran-ajaran Islam atau menyebarluaskan ajaran Islam, melakukan upaya perbuatan kearah kondisi yang lebih baik menurut ajaran islam, Pada dasarnya tugas pokok bagi seorang da'i adalah meneruskan Rasul Muhammad SAW, ia adalah pewaris Nabi yang berarti harus menyampaikan ajaran-ajaran Allah SWT., 2) Mad'u merupakan pihak yang diajak kejalan Islam. Secara umum mad'u memiliki kemampuan yang berbeda-beda. mengemukakan bahwsannya ada dua potensi yang dimiliki oleh mad'u yang dapat dijadikan acuan oleh da'i dalam menyampaikan pesannya (Aliyudin, 2009:74).

Masyarakat sebagai objek dakwah sangat heterogen, misalnya ada masyarakat yang berprofesi sebagai nelayan, petani, pegawai, guru, buruh, karyawan dan yang lainnya. Bila kita melihat dari aspek geografis, masyarakat ada yang tinggal di desa ataupun kota, pegunungan atau pesisir bahkan ada yang tinggal di pedalaman (Saputra, 2011:8).

Mad'u yang menerima pesan dengan baik akan mengaplikasikannya sesuai dengan kemampuan yang dimilikinya, kemudian pesan itu akan terselenggara denga sendirinya oelh mad.u. 3) Pesan dakwah berupa informasi yang dapat memotivasi audiens diambil dari ajaran agama dan disertai dengan penjabarannya. Selain itu pesan dakwah harus mengusung tema yang relevan yang sesuai dengan keadaan masyarakat dan selalu menyampaikan nilai Islam yang bisa mendatangkan makna dan manfaat. Seperti yang dikemukakan. Kesuksesan dakwah dilihat dari penyusunan materi yang akan disampaikan, pesan dakwah akan memilki kesan dan dirasa menarik, apabila pengemasan materi dakwah disampaikan dengan sesuai keadaan mad'u dan melalui penyusuanan mteri dakwah yang sempurna.. 4) metode dakwah, sebagai pesan dakwah yang tidak akan pernah sampai kepada mad'u tanpa adanya metode, dengan demikian metode merupakan sesuatu yang menghubungkan pesan antara da'i dengan mad'unya (Aliyudin, 2009:108).

Alquran surat An-Nahl ayat 125, diterangkan mengenai metode dakwah, yaitu metode hikmah, mau'idzoh, dan mujadalah. 5) media dakwah, adalah penyambung, menghubungkan sesuatu kepada tujuan atau mengatarkan segala sesuatu yang dimaksud. Suatu metode tidak akan berjalan tanpa adanya media. Dengan demikian media dakwah merupakan instrument yang dilalui oleh pesan dakwah atau saluran pesan yang menghubungkannya antara da'i dan mad'u. 
Komponen-komponen diatas tidak jauh dan tidak dapat terpisahkan dengan materi, selanjutnya materi dalam dakwah melalui tulisan menekakan pada isi pesan yang disampaikan oleh seorang penulis, agar pembaca dapat mengetahui secara menyeluruh pesan apa yang disampaikan oleh penulis dari buku tersebut, kemudian dapat dikatakan bahwa pesan merupakan seperangkat simbol baik itu verbal maupun non verbal yang diperuntukan untuk menyatakan suatu maksud tertentu, pesan memiliki tiga komponen yakni makna, simbol atau lambang dan bentuk atau organisasi yang digunakan untuk menyampaikan suatu maksud tertentu.

Pesan yaitu apa yang dikomunikasikan oleh sumber kepada penerima. Pengertian ini berdasarkan pada lima unsur komunikasi Laswell yang salah satunya adalah pesan, pesan merupakan seperangkat simbol verbal dan atau non verbal yang mewakili perasaan, nilai, gagasan atau maksud sumber tadi. "Pesan mempunyai tiga komponen: makna, simbol, yang digunakan untuk menyampaikan makna, dan bentuk atau organisasi pesan" (Mulyana, 2001:70).

Dakwah melalui tulisan merupakan penyampaian pesan dakwah menggunakan media tulisan, diantaranya: buku, majalah, surat kabar, risalah, buletin, brosur, dan lainnya. Dalam memanfaatkan media ini, hendaknya ia ditampilkan dalam bahasa yang lancar, mudah dipahami dan menarik minat publik, baik kalangan awam maupun terpelajar. Sebagamana yang disebutkan dala Al Quran surat Nun ayat 1. Dalam hal ini Al-Qurtubi menyatakan bahwa tulisan adalah suatu penjelasan sebagaimana lidah dan qalam yang dipakai menulis (oleh Allah Swt.) baik yang ada di langit maupun yang ada di bumi. Jadi penjelasan al-Qurtubi menunjukkan bahwa qalam adalah sebuah alat untuk merangkai tulisan, lalu berkembang menjadi alat cetak mencetak.

Al-Shabuni mengungkapkan bahwa qalam atau tulisan adalah pena untuk menulis, alat untuk mencatat berbagai ilmu dari ilmu yang ada dalam kitab Allah Swt. hingga apa yang menjadi pengalaman manusia dari masa ke masa (Kasman, 2004:119).

Tulisan sebagai media dakwah dapt melayani kebutuhan masyarakat akan informasi Islam. informasi Islam yang dimakud disini adalah informasi yang bersumber dari Alquran dan Hadits. Berupaya mewujudkan atau menjelaskan seruan Alquran secara cermat melalui berbagai media cetak untuk mengemabalikannya kepada fikrah dan keuniversalannya serta menyajikan prosuk-produk Islam yang elaras dengan pemikiran. Menghidupkan dialogdialog bernuansa pemikiran, politik, budaya, sosial, dan lain-lain.

Analisis isi digunakan untuk memperoleh keterangan dari komunikasi yang disampaikan dalam bentuk lambang yang terdokumentasi atau dapat didokumentasikan. Analisis isi dapat dipakai untuk menganalisa semua bentuk komunikasi seperti, pada surat kabar, buku, film, dan lain sebagainya. 
Penggunaan metode analisis isi akan memperoleh suatu pemahaman terhadap berbagai isi pesan komunikasi yang disampaikan oleh media massa atau dari sumber lain secara objektif, sistematis dan relevan. Maka dari itu upaya untuk membedakan dan menganalisis isi pesan yang terdapat dari surat kabar, radio bahkan televis bisa menggunakan analisis isi (conten analysis) (Subrayogo, 2001:6).

Analisis isi berhubungan dengan komunikasi atau isi komunikasi. Memiliki tujuan menarik kesimpulan penyebab dari suatu pesan. Fokus analisis isi disini yaitu menjawab pernyataan mengapa pesan (isi) muncul dalam bentuk tertentu, sebaliknya bukan deskripsi isi pesan.

\section{HASIL DAN PEMBAHASAN}

Penelitian ini dilakukan pada buku yang berjudul Gapleb "Gaul Tapi Soleb" merupakan karya dari Usdaz Evie Effendie yang pertama, peneliti akan menjelaskan tentang profil penulisnya yaitu. Usdaz Evie Effendie da'i kelahiran Bandung, 19 Januari 1976. Sosok penceramah yang sedang viral dan fenomenal dengan gayanya yang gaul, unik, nyentrik dan inspiratif yang menjadi daya tarik dakwhnya terutama untuk kalangan anak muda. Karenanya, beliau akrab dijuluki Ustadz Gapleh “Gaul Tapi Soleh”. Ceramah-ceramahnya viral di media social dan menjadi inspirator kelompok-kelompok "jalanan" untuk hijrah dari dunianya. Buku yang diterbitkan ini merupakan petikan dari ceramah-ceramah viral Ustadz Evie Effedie yang dimodifikasi dan dikolaborasikan dengan penulisnya yakni Ustad Abdurrohim.

Ustadz Abdurrohim, M. Ag, lahir di Garut, 27 Mei 1978. Dikenal dengan nama Ustadz Rohim, aktivitas sehari-harinya adalah mengajar di Pesantren Persis Lempong Banyuresmi Garut, Dosen di Sekolah Tinggi Agama Islam Persatuan Islam (STAIPI) Garut, aktif sebagai da'i, menulis buku, mengisi training motivasi Alquran, serta mengisi pelatihan "cara cepat membaca Alquran 2 jam" di berbeda tempat.

Buku karya Ustadz Evie Effendie menjelaskan bagaimana proses berhijrah seseorang dengan menggunakan singkatan-singkatan yang sudah banyak orangorang mengetahuinya, mengutip dalam bukunya "Jangan sia-siakan masa muda memang benar menikmati masa muda itu mesti gaul, tapi tentu saja gaulnya harus gaul yang positif. Kalau gaulnya cuman nongkrong-nongkrong, motor-motoran, ngafe ngabisin duit itu cuman gaul yang sangat biasa". Tips-tips gaul seputar ke Islaman dirangkum dalam sebuah buku yang bernama Gapleb "Gaul Tapi Soleh". Orang-orang akan menemukan istilahistilah unik yang sesuai dengan kriteria anak muda yang dikemas secara kekinian dan gaul.

Hasil dari penelitian ini adalah Pesan Dakwah Akidah Dalam Buku Gapleh (Gaul tapi soleh), Pesan Dakwah Syari'ah Dalam Buku Gapleh (Gaul tapi soleh), Pesan Dakwah Akhlak Dalam Buku Gapleh (Gaul tapi soleh). 


\section{Pesan Dakwah Akidah Dalam Buku Gapleh (Gaul tapi soleh)}

Pesan akidah adalah suatu materi atau ajaran Islam yang memfokuskan pada sisi ke-tauhid-an atau keimanan manusia kepada Allah SWT, juga mengimani para malaikat-Nya, mengimani kitab-Nya (Alquran), mengimani para Nabi dan RasulNya, mengimani qada dan qodar, mengimani hari akhir (kiamat), dan segala apa yang diciptakan-Nya. Yakin bahwa hanya Allah lah yang layak untuk disembah, dan tidak menyekutukannya atau berbuat syirik.

Dalam buku Gapleh "Gaul Tapi Soleb”, terdapat beberapa pesan akidah yaitu sebagai berikut: Iman kepada Alquran, Mempercayai terhadap ketentuan yang telah diberikan oleh Allah merupakan pondasi bagi seseorang untuk meyakini dalam hatinya bahwa dirinya memiliki keimanan. Diantara keimanan itu dapat dilihat dari sikap yang dilakukan oleh seseorang dalam kehidupan sehar-hari, baik itu dalam keluarga maupun bermasyarakat. Ditanamkannya akidah pada diri seseorang tidak lain hanya untuk menumbuhkan rasa kepercayaan terhadap tuhan yang telah menciptakan dirinya dan sisi alam dunia.

Doa, Setiap manusia pasti memiliki keinginan yang berbeda-beda, untuk mencapai keinginan itu tentu harus disertai dengan usaha. Usaha akan lebih ringan jika dibarengi dengan berdoa (memohon) kepada Allah sehingga hati lebih ikhlas (lillah) ketika melakukan usaha. Ustadz Evie dalam buku Gapleh "Gaul Tapi Soleb” menyampaikan kepada kita untuk berdoa.

Dzikir, Langkah untuk memantapkan move on atau berhijrah yaitu melalui berdzikir kepada Allah. Amalan dzikir sangat kuat untuk mendukung move on atau proses berhijrah. Alasannya, dzikir berfungsi untuk menentramkan hati dan menenangkan jiwa. The powe of Drikir bias untuk mengusir hati yang galau, risau, dan kacau balau. Jadi insya Allah saat kita menjalani hijrah atau move on, hati kita diberikan ketenangan karena terus berdzikir. Maka, berdzikirlah dengan ingat kepada Allah dulu, ingat Allah lagi, lagi-lagi Allah, dan ingatlah Allah terus dalam hati kita. Basahi lidah kita dengan menyebut asma-Nya dan kalimat-kalimat thoyibah juga sertakan Allah dalam setiap gerak langkah kita lewat doa.

Kekuatan dzikir lainya ialah sebagai banteng diri kita dari kembali melakukan kegiata yang bergelimang dosa. Dengan terus berdzikir kepada Allah, insya Allah kita akan terajaga dari kecanduan berbuat maksiat. Seperti sabda Rasul dalam hadistnya yang artinya "tidak ada dosa besar jika terus menerus dikikis dengan istighfar". Melalui dzikir hati kita akan tentram saat hijrah dan amalanamalan dzikir menjadi penghapus dosa besar.

Hijrah, Dalam isi buku Gapleh "Gaul Tapi Soleh” Ustadz Evie Effendie menyampaikan adanya tingkatan kebaikan yang dirasakan oleh manusia yaitu, berpindahnya akhlak seseorang dari pribadi yang tercela menjadi pribadi yang terpuji dengan meniti jalan hijrah. Hijrah yang disampaikan oleh penulis bisa jadi sesuai pengalaman yang dialami oleh penulis buku Gapleh "Gaul Tapi Soleb". 
A Saepulloh, T Fachruddin, Yuliani

Terdapat banyak motivasi yang disampaikan salah satunya, kita dituntut untuk tidak takut mengambil jalan kebaikan. Hijrah tersebut Ustadz Evie Effendie memberikan nama dengan kata "move on" yang bermakna pindah, bergerak dalam hal lain berpindah dan bergerak dari jalan yang sesat kepada jalan yang benar untuk menjadi pribadi yang lebih baik. Dari kutipan tersebut dapat kita ketahui untuk menjadi pribadi yang lebih baik seseorang harus mampu meninggalkan hal-hal yang tidak baik.

Adanya tulisan yang disampaikan oleh Ustadz Evie Effendie dapat dipakai sebagai langkah pertama untuk melakukan hijrah atau move on bagi kalangan yang membutuhkan karya-karya mengenai proses hijrah Ustadz Evie Effendie sendiri.

Manjaga Hati, Dalam kehidupan pasti bertemu dengan berbagai masalah terutama dalam menghadapi hubungan sosial antara diri kita dan orang-orang sekitar. Ada salah satu masalah yang sering timbul, kesalahan yang biasa tapi memberikan efek yang begitu beras seperti sakit hati. Dalam buku Gapleb "Gaul Tapi Soleh" Ustadz Evie Effendie mengemukakan bagaimana cara menghindari timbulnya masalah sakit hati, yaitu untuk senantiasa selalu menjaga hati dari sifat-sifat kikir, ria, hasud, dan lain sebagainya.

Aa Gym sering menyebutkan dalam ceramahnya, apabila hati kita bersih pikiran pun akan jernih, semangat hidup nan gigih, prestasi mudah diraih. Namun, bila hati busuk pikiran jahat merasuk, akhlak kiat terpuruk jadi makhluk terkutuk. Jagalah hati jangan kau nodai, jagalah hati lentera hidup ini. Maksud dari penyampaian tersebut, kita diingatkan agar senantiasa menjaga hati agar dimudahkan segala urusan kita dan menjaga agar hati kita tidak ternodai oleh hal-hal yang tidak disukai oleh Allah SWT.

Syirik, Dalam menjalankan ibadah kita harus menjaga amalan-amalan supaya senantiasan diterima dan mengapatkan pahala dari Allah SWT. Amalanamalan ibadah yang kita lakukan bisa hilang pahalanya, ibarat air di atas daun talas, tidak ada bekasnya sama sekali.

Syirik adalah salah satu yang akan membuat amal ibadah kita hangus, karena syirik merupakan dosa yang amat besar, seperti dalil Allah dalam surat alBayyinah ayat 15 bahwa kita dilarang untuk menyembah selain kepada Allah, ketika kita menyembah patung, matahari, dan benda-benda lainnya maka kita telah berbuat syirik.

Syirik yang tersembunyi dalam buku Gapleb "Gaul Tapi Soleb" yaitu kepercayaan terselubung kepada selain Allah SWT yang dipercaya bisa mendatangkan kekuatan ini dan itu. Misalnya percaya terhadap dukun, ramalan, benda sakti (jimat), kuburan, pohon, dan sebagainya yang istilahnya dapat mendatangkan karomah atau keramat, diantaranya dipercayara bisa melancarkan karir, melancarakan dalam berbisnis, dan berbagai macam lainnya yang bisa membereskan urusan manusia.

Iman, Dalam buku Gapleb “Gaul Tapi Soleh” dijelaskan bahwa iman, akidah, 
atau tauhid merupakan pondasi untuk menghadapo gelombang ujian. Iman merupakan modal penting untuk membuat hidup kita tenang dan bahagia. Tanpa keimanan kita akan rapuh, mudah galau, gampang putusasa ketika menghadapi masalah demi masalah karena tidak memiliki sandaran hidup. Bahkan yang lebih bahanyanya hati kita akan dikendalikan oleh hawa nafsu.

Maka dari itu keimanan harus senantiasa menjadi modal utama yang benar-benar dijaga kekokohannya, supaya hidup kita dapat menemukan ketenangan dan bahagia, seperti konsep yang diajarkan dalam buku Gapleh "Gaul Tapi Soleh" yaitu harus Instagram yang artinya "iman, sabar, dan syukur mendatangkan rasa tentram".

Pesan adalah materi yang dimiliki oleh sumber untuk dibagikan kepada orang lain. Dalam bentuknya pesan merupakan sebuah gagasan yang telah diterjemahkan kedalam simbol-simbol yang diperuntukan untuk menyatakan suatu maksud tertentu (Liliweri, 1991:23).

Pesan yaitu apa yang dikomunikasikan oleh sumber kepada penerima. Pengertian ini berdasarkan pada lima unsur komunikasi Laswell yang salah satunya adalah pesan, pesan merupakan seperangkat simbol verbal dan atau non verbal yang mewakili perasaan, nilai, gagasan atau maksud sumber tadi. "Pesan mempunyai tiga komponen: makna, simbol, yang digunakan untuk menyampaikan makna, dan bentuk atau organisasi pesan" (Mulyana, 2007:70).

Menurut Onong Uchayana Effendi bahwa massage yaitu pesan yang merupakan seperangkat lambang bermakna yang dilambangkan oleh komunikator, Pesan-pesan komunikator disampaikan melalui simbol-simbol yang bermakna kepada penerima pesan. Pesan mempunyai tiga komponen makna, simbol yang digunakan untuk menyampaikan makna dan bentuk atau organisasi pesan (Uchayana, 2005:18).

\section{Pesan Dakwah Syari'ah Dalam Buku Gapleh (Gaul tapi soleh)}

Syariah merupakan aturan atau ketetapan yang Allah perintahkan kepada makhluk-Nya, seperti puasa, shalat, zakat, dan lain sebainya. Syariah ini merupakan ibadah yang senantiasa harus dilakukan oleh setiap orang yang memeluk agama Islam, dimana ibadah yang dilakukan seseuai dengan apa yang telah Allah perintahkan dalam Alquran dan Rasul contohkan dalam Hadist. Dalam buku Gapleh "Gaul Tapi Soleb” terdapat beberapa pesan Syariah diantaranya sebagai berikut:

Salat, Ketika manusia lahir dalam ke adaan suci dan muslim. Jika dilahirkan dalam keluarga yang memang beragama Islam maka sudah jelas akan menganut agama Islam, dimana setiap agama memeliki perintah atau kewajiban untuk melakukan ibadah kepada tuhan. Begitu pula dengan ajaran dalam Islam bahwa seseorang muslim/muslimah diwajibkan untuk beribadah yaitu dengan 
mengikuti segala perintah-Nya dan menjauhi segala larangan-Nya. Karena ketika mati semua amalan ibadah akan di perhitungkan.

Ustadz Evie dalam buku Gapleb “Gaul Tapi Soleh” mengingatkan kita untuk tetap setiap melakukan salat, karena salat adalah pondasi awal yang harus terus dijaga ke kokohannya. kata kunci yang di berikan Ustadz Evie dalam buku Gapleh SMS yang artinya "Segera Mengerjakan Salat", Line yang artinya "Lima Waktu on Time". Tanda orang beriman dan bersyukur kepada Allah adalah salatnya. Kalua kita merasa sudah diberi nikmat yang tak terhingga oleh Allah maka bersyukurlah dengan cara melaksanakan salat dengan sebaik-baiknya.

Berhijab, Ayat Alquran di atas menjelaska bahwa ada seuatu perintah Allah yang diwajibkan untuk para kaum wanita, yaitu agar kaum wanita bias menutup aurat (berhijab). Karena wanita nilai keindahan yang harus dapat dijaga oleh dirinya dengan berhijab, selain itu dengan berhijab dapat menjauhkan wanita dari beberapa hal-hal yang berbahaya, contohnya ketika wanita menggunakan pakaian yang memperlihatkan bentuk tubuhnya, ketia seorang laki-laki melihatnya akan mengundang hawanafsunya. Apabila laki-laki tersebut tidak bias menahan hawanafsunya sampai kehilangan akal sehatnya kemudian nekad untuk melakukan hal yang diluar aturan baik itu agama dan negara yaitu memperkosa perempuan tersebut.

Penjelasan yang disampaikan Ustadz Evie tadi dapat disimpulkan bahwa ketika wanita berhijab bukan hanya saja sebagai kewajib dalam melaksanakan perintah dari Allah, akan tetapi dengan berhijabnya seorang wanita itu akan menghindarkan diri dari bahaya. Tambahnya lagi ketika wanita berhijab dari segi kesehatan rambut yang senantiasa tertutupi akan terlindungi dari kotoran debu ketika wanita itu berada diluar ruangan sehinnga rambutnya tetap bersih dari kotoran.

Memakmurkan Masjid, "Hebat, bukan. Kalau yang rajin ke masjid adalah para manusia atau orang-orang lanjut usia, itu sudah biasa. Yang bagus itu ketika para pemuda yang rajin ke masjid dan hatinya selalu tertambat ke masjid untuk salat berjamaah, berzikir, atau mengikuti kegiatan majelis taklim". (Effendie, 2018:23)

Penjelasan Ustadz Evie Effedie di atas dalam buku Gapleh "Gaul Tapi Soleh", mengajak kita semua selaku umat muslim-wal-muslimah untuk senatiasa memakmurkan masjid. Karena masjid di bangun bukan untuk jadi objek wisata, dan bukan hanya untuk tempat kumpul umat pada hari jumat saja, namun masjid harus menjadi tempat ibadah yang benar-benar penghuninya ramai dan berbondong-bondong.

Zakat, infak atau sedekah, Menjadi suatu keharusan dalam kehidupan kita selaku umat muslim untuk melakukan ibadah kepada Allah SWT. Banyak macam-macam ibdah yang harus kita lakukan, ada yang disebut dengan ibadah Maliyah yaitu ibadah lewat harta benda, contohnya seperti zakat, infak, dan 
sedekah. Dengan melakukan ibadah tersebut adalah sebagai bentuk rasa syukur kita kepada Allah atas nikmat rizki yang telah diberikan, selain itu juga sebagai penyuci jiwa dan pembersih harta.

Dalam buku Gapleh “Gaul Tapi Soleh” Ustadz Evie Effendie menjelaskan yang berkaitan dengan zakat, infak, dan sedekah. Berikut kutipan menggunakan singkatan-singkatan beserta penjelasannya pada buku tersebut: 1) Bersahaza, Dalam Alquran, zakat selalu disandingkan dengan salat, kita pasti sering menemukan ayat aqimussalat wa aturzakat yang artinya dirikianlah salat dan keluarkanlah zakat. Berarti, hukumnya sama-sama wajib dilaksanakan. Jika telah menjadi pengusaha muda, jangan pernah lupa untuk mengeluarkan zakatnya, biar usahanya makin berkah. Ingat hidup itu mesti Bersahaza (Berkah Usaha dengan Zakat). 2) IPK dan STTB, Yakinlah ketika kita berinfak di jalan Allah maka akan mendapatkan IPK (Infak Pangkal Kaya), dan yakin bahwa setiap kali kita besedekah maka akan mendapatkan STTB (Sedekah Terus Tambah Berkah), (Sedekah Terus Tolak Bahaya), dan (Sedekah Terus Tidak akan Bangkrut). Maka dari itu jangalah kita bersikap pelit.

Ketika hati berat atau bahkan tidak ada kemauan untuk mengeluarkan sedekah maka harta yang dikumpul-kumpulkan itu kelak di akhirat akan menjadi ular yang terus-menerus memakan pemiliknya. Jadi selamatkanlah harta yang kita miliki untuk mendapatkan berkah dari Allah SWT. Dengan tiga kata kunci yang tadi disampaikan oleh Ustadz Evie yaitu, dengan Bersahaza (Berkah Usaha dengan Zakat), IPK (Infak Pangkal Kaya), dan STTB (Sedekat Terus Tambah Berkah), (Sedekah Terus Tolak Bahaya) dan (Sedekah Terus Tidak akan Bangkrut).

Memanfatkan Waktu, Kenikmatan yang telah Allah berikan kepada kita ketika hidup di dunia tidak dapat kita hitung, nikmat sehat yang tidak ternilai harganya, nikmat harta yang tidak terhitung jumlahnya, dan semua kenikmatan lain yang telah Allah berikan tanpa kita sadari. Dalam buku Gapleb "Gaul Tapi Soleh" Ustadz Evie Effendie menyampaikan bahwa nikmat Allah kita rasakan setiap detik, maka seharusnya setiap detik pula ibadah kita laksanakan.

Islam sebagai pesan dakwah tidak akan pernah sampai kepada mad'u tanpa adanya metode, denga demikian metode merupakan sesuatu yang menghubungkan pesan antara da'i dengan mad'unya. Metode berasal dari bahasa Yunani yaitu methodos, merupakan gabungan dari kata meta yang berarti melalui dan hodos yang berarti jalan (Aliyudin, 2009:82).

Pesan dakwah sudah menjadi syariat Islam yakni sebagai kebenaran hakiki yang datang dari Allah melalui malaikat jibril kepada para nabi-Nya dan terakhir kepada nabi Muhammad SAW. (Sambas, 2004:55).

Alquran menyiratkan semua pesan dakwah dan dijabarkan oleh nabi dalam al-Hadits. sedangkanan pengembangannya kemudian akan mencakup seluruh 
kuitur islam yang murni yang bersumber dari kedua pokok ajaran islam itu (Kafie, 1993:35).

\section{Pesan Dakwah Akhlak Dalam Buku Gapleh (Gaul tapi soleh)}

Akhlak merupakan salah satu sistem nilai yang dapat mengatur tindakan atau sikap manusia dalam kehidupan sehari-harinya, sistem nilai tersebut yaitu ajaran Islam yang bersumber pada Alquran dan Hadist, lalu ada ijtihad sebagai metode berfikir Islam. Tindakan dan sikap yang dilakukan dalam keseharian manusia tersebut terbagi kedalam tiga, yaitu hunbungan kepada Allah SWT, kepada manusia, dan alam. Masih banyak tindakan kita sebagai muslim yang belum sesuai dengan yang seharusnya (ajaran Islam), maka ada beberapa pesan akhlak dalam buku Gapleh yaitu sebagai berikut:

Bersosialisai (Pergaulan), Dalam kehidupannya manusia memiliki dua sisi yang berbeda yaitu sisi buruk dan sisi baik pada akhlaknya dalam buku Gapleh terdapat tulisan yang mengajarkan mengenao prinsip pergaulan, "yaitu boleh kenal dan bergaul dengan siapa saja, bahkan antar suku dan bangsa". Dalam kutipan tersebut dapat diuraikan bahwa akhlak seseorang dapat dikategorikan, bahkan dapat dilihat oleh diri sendiri dan orang lain.

Dalam buku Gapleh “Gaul Tapi Soleb” pada kutipan di atas merupakan perintah untuk menjaga akhlak seseorang kepada siapapun, baik itu kesopanan dalam berbicara, maupun berkelakuan. Karena dalam mengenali siapapun dibutuhkan akhlak baik agar diterima dimanapun. Ustadz Evie Effendie dalam bukunya memberikan beberapa contoh gaul diantaranya: a) main Gapleh, "Gaul tapi Soleh" maksudnya bergaul dengan siapapun mesti membuat kita tambah soleh. Jadi bukan gapleh nongkrong bareng main kartu. b) main Games "Gaul itu Aktif ke Masjid" maksudnya rajin mengikuti taklim atau salat berjamaah. Jad bukan main games seperti play station, nongkrong di warnet, atau games sia-sia lainnya. c) main Catur "Membaca Alquran Teratur" maksudnya kita mesti punya jadwal rutin membaca Alquran. Lebih bagusnya one day one juz. Tapi kalau masih berat bisa beberapa ayat saja dalam sehari yang penting ruti. d) Galaksi "Gaul Aktif Berprestasi" maksudnya gaul mesti menambah ilmu, wawasan dan buat kreasi yang positif dan karya yang berguna.

Ikhtiar, Usaha atau ikhtiar wajib dilakukan sebagai penyempurna doa. Ada yang bilang "doa tanpa usaha kososng, usaha tanpa doa sombong". Jadi, antara doa dan usaha harus sama kuat atau balance. Untuk mencapai cita-cita atau menyelesaikan masalah maka usaha kita wajib maksimal. Istilahnya, "sampai tititk darah penghabisan". Misalnya, untuk meraih cita-cita, tentu tidak cukup dengan doa, bukan? Kalua orang Arab bilang, "Walalladzata illa ba'da ta'ab", kalau orang Inggris bilang "no pain no gain", kira-kira artinya sama "tidak ada kesuksesan kecuali telah bekerja keras”. Ingat saja bagaimana burung bias hidup, ia tidak diem ia tidak diem terus di sarangnyakan? Ia selalu semangat terbang 
pagi-pagi berusaha mencari makan padahal perutnya kosong, dan kembali pulang saat perutnya sudah terisi. Malah, induk betina sambal mencari makan untuk anak-anaknya. Itulah "the power of man jadda wajada", siapa yang bekerja keras pasti dia berhasil. Jadi padukan kekuatan doa dan usaha (ikhtiar) kita, insya Allah apa yang kita inginkan berhasil.

Ikhlas, Dalam buku Gapleh "Gaul Tapi Soleb” Ustadz Evie Effendie menyampaikan agar kita senantiasa ikhlas dalam menghadapi segala kondisi yang kita alami, seperti pada kutipan buku Gapleh "Gaul Tapi Soleb” dijelaskan bahwa ikhlas hanya karena dan kepada Allah merupakan tujuan dari apa yang kita lakukan.

Pesan ikhlas yang telah Ustadz Evie Effendie sampaikan di atas, telah memberikan gambaran bahwa kita usaha harus dengan ke ikhlasan hati yang mana hanya mengharapkan ridha Allah. Jika tidak di kerjakan dengan ikhlas makan akan memberikan dampak yang amat negatif, contohnya ketika seseorang gagal dalam melakukan sesuatu kemudian dia putusasa dan ujung-ujungnya melakukan hal yang berbahaya seperti bunuh diri, mabok-mabokan, dan lain sebagainya. Maka dari itu doa, usaha, dan ikhlas ini jangan sampai terpisahkan.

Tawakal, Dalam buku Gapleh "Gaul Tapi Soleh" Ustadz Evie Effendie menyampaikan untuk bersikap tawakal, berikut kutipan mengenai tawakal. Setelah kita berdoa, beusaha, dan ikhlas karena Allah, maka sempurnakan ikhtiar terbaik kita dengan tawakal. Tawakal artiya menyerahkan segala urusan kepada Alllah sebagai pemutus hasil terbaik urusan setelah kita berusaha maksimal. Manusia wajib menenmpuh proses, tetapi tidak bias dijamin pasti Allah akan menolong sampao kita mendapatkan yang terbaik, inilah jaminan Allah, Wa may yatawakeal 'alallah fahuwa hasbubu, artinya "Barang siapa yang bertawakal, berbulat hati menyerahkan segala urusan kepada Allah setelah berusaha, maka niscaya Allah akan cukupkan". Jadi ingat-ingat bahwa untuk meraih yang terbaik mesti pake DUIT, "Doa, Usaha, Ikhlas, dan Tawakal".

Taubat, Dalam buku Gapleb "Gaul Tapi Soleb" kutipanya Ustadz Evie Effendie menyampaikan. Pastinya tidak ada manusia yang suci dari salah satu dan dosa. Tetapi Allah Maha Pengampun yang selalu membuka pintu ampunanNya selebar-lebarnya dan seluas-luasnya. Dosa-dosa kita sebanyak apapun akan Allah ampuni dengan syarat ACT "Aksi Cepat Taubat". Janganlah sekalipun kita putus asa dari kasih sayang Allah. Hanya ternyata karena merasa banyak dosa keluar statement "dosa terlalu banyak, tidak mungkin diampuni". Ucapan itu tidak boleh keluar dari mulut kita. Ampunan Allah itu lebih luas dari pada dosa manusia, asal kita taubatnya benar (taubatan nasuba) bukan jadi-jadian atau istilahnya "Tomat" alias "Taubat Kumat".

Jujur, merupakan prilaku yang sangat mulia, ketika kita menjadi pribadi yang jujur makan orang-orang disekitar akan mempercai apapun kepada kita. 
Memang bukan hal sulit untuk bersikap jujur, namun karena banyak godaan dari syaitan sehingga bias saja kita lengah dan tidak belaku jujur. Dalam buku Gapleh "Gaul Tapi Soleh" Ustadz Evie Effendie menyampaikan lebih jelas mengenai apa itu jujur, berikut kitupannya. Salah satu ajaran mulia dalalm Islam adalah mengerjakan sikap jujur. Idola kita, Nabi Muhammad Saw, mengatakan bahwa jujur merupakan pangkal segala kebaikan dan setiap kebaikan akan mengatar kita ke surga.

Menjauhi Zina, Mendekati saja sudah menjadi larangan bagi kita, apalagi melakukan zina. Sebelum kita menjahui zina maka pertama-tama kita harus mengetahui terlebih dahulu apa saja yang termasuk perbuatan zina. Dalam buku Gapleh "Gaul Tapi Soleh” Ustadz Evie Effendie menjelaskan kebiasaan yang termasuk zina dengan menggunakan password/ singkatan-singkatan yaitu sebagai berikut: a) Jerawat, Jerawat merupakan singkatan dari "Janganlah engakau berkhalwat". Maksudnya, dalam agama Islam, pacarana itu dilarang atau lebih tegasnya haram ketika diantara seorang laki-laki dan perempuan yang bukan mahram melakukan khalwat. Yang dimaksud berkhalwat yaitu contohnya berdua-duan di tempat sepi, pegang-pegangan tangan dan lainnya, b) Pan Japa, yaitu "Pastikean tahan jarak dan pandangan". Maksudnya ketika bergaul dengan siapapun lebih khususnya ketika bergaul dengan lawan jenis, maka kita wajib untuk menjaga jarak dan padangan, yang di maksud jaga jarak disini yaitu jangan sampai rempet-rempetan, kemudian jaga pandangan yaitu tidak boleh main pandang-pandangan.

Berbakti kepada orang tua, Sebagai buku yang diminati oleh kalangan remaja dan muda-mudi tentunya Ustadz Evie Effendie juga menyisipkan pesan-pesan mengenai bagaimana cara kita bersikap menghormati dan berbakti kepada kedua orang tua. Seperti yang disampaikan dalam buku Gapleb "Gaul Tapi Soleb”.

Ajaran mulia dalam islam, yakni berbakti kepada ayah dan ibu selaku orangtua kita. Berusahalah untuk selalu berbakti kepada mereka, please jangan deh kita sampai menyakiti hati mereka. Ingat, guys! Ridhanya Allah bergantung pada ridha Ayah dan Ibu. Sebaliknya, murka Allah pun bergantung pada murka Ayah dan ibu juga. Bila Ayah dan Ibu ridha maka Allah pun ridha. Sebaliknya, jika Ayah dan lbu murka, maka Allah akan murka. Berbaktilah, berbuat baiklah kepada mereka, patuhilah nasihat-nasihatnya. Janganlah membuat hidup mereka karena kelakuan buruk kita. Jasa mereka tak terhitung, tak ternilai, dan tak akan terhingga. Mereka mengurus kita dari kecil hingga dewasa dan sepanjang masa. Berbaktilah kepada mereka selama mereka masih hidup. Doakan terus mereka jika mereka sudah tiada.

Menjaga Lisan, Jagalah lisan, jaga ucapan, jangan sempai melukai hati orang lain. Ada beberapa penyakit lisan yang harus kita jauhi, yaitu: Tuhmah (memfitnah), Gibah (membicarakan kejelekan orang lain), Namimah (mengadu domba), Dusta, Sombong, Riya atau Sum'ah (kata-kata ingin dipuji), Ucapan- 
ucapan yang "lagho" atau ucapan yang tidak bermanfaat.

Terlebih, zaman sekarang, saat para pelajar sudah terbiasa berkata kasar, kotor, seperti "bahasa-bahasa binatang. Sebagai pemuda-pemudi Islam, yuk kita amalkan ajaran Islam yang keren seperti yang disabdakan Rasulullah SAW. Qul khairan aul liyashmut, alias Rabadi, yaitu "Bicara Baik-baik atau Diam". Jadi, bicaralah yang baik, jika tidak bisa, maka diam adalah yang terbaik.

Budaya, Budaya itu ada yang positif dan ada yang negatif. Salah satunya budaya asing, pasti ada sisi positif dan negatifnya. Kita sebagai muslim dan orang"timur" tidak boleh juga menelan bulat-bulat semua budaya yang datang dari luar. Yang disebut budaya adalah semua produk manusia, baik berupa barang maupun suatu kebiasaan Budaya barat tidak bisa semuanya diterima walaupu tidak semua mesti ditolak. Budaya positif yang datang dari barat, misalnya ilmu pengetahuan teknologi. Harus diakui kalau ilmu pengetahuan dan teknologi orang-orang barat memang sudah lebih maju. Sebut komputer dan handphone yang merupakan ikon kehebatan dari budaya barat. Saat ini, seolaholah dunia bisa "digenggam" hanya dengan membuka internet dari handphone kita. Luar biasa! Tentu saja, kita ngga bakal mungkin bisa nolak arus ini, tinggal bagaimana kita akan memperlakukannya: bisa positif, bisa negatif.

Datangnya sebuah keadaan dimana budaya asing masuk melalui arus globalisasi yang sebagian besar diperankan oleh media sosial. Biasanya, para anak muda yang belum dapat membedakan mana budaya dari luar yang dapat membawa pengaruh positif atau negatif akan menelannya mentah-mentah, sehingga apa yang dilihat akan langsung ditiru dan diaplikasikan dalam kehidupan sehari-hari tanpa tahu bagaimana dampak baik atau buruk ke depannya.

Melalui buku Gapleh “Gaul Tapi Soleh”, Ustadz Evie Effendi menjelaskan bahwa dalam sebuah hadits menyebutkan bahwa jika seseorang meniru perbuatan sebuah kaum, maka dia termasuk dari kaum tersebut. Atau dalam sebuah ayat Alquran menjelaskan bahwa jika seseorang menyerupai perbuatan sebuah kaum, maka pada saat hari kiamat dia akan dibangkitkan bersama kaum tersebut. Ini berarti, Ustad Evie Effendi berusaha mengingatkan bahwa dalam sebuah kebudayaan yang dibawa oleh suatu kaum, kita sebagai umat Islam tidak boleh terlalu fanatik dengan kebudayaan tersebut. Bisa jadi kaum yang menyebarkan atau membawa kebudayaan tersebut merupakan suatu pengaruh yang buruk, sehingga dapat merugikan kita hingga hari akhir nanti.

Memaafkan, sebagai makhluk hidup yang bersosial pasti pernah melakukan kesalahan kepada sesame atau orang-orang yang berada disekitar kita. Ketika kita melakukan kesalahan makan hal yang akan kita lakukan adalah meminta maaf, sebaliknya ketika orang berbuat salah kepada kita maka hendaklah kita bisa dengan lapang memaafkannya. 
Kata-kata yang demikian janganlah sampai kita ucapkan, sungguh benar bahwa untuk memaafkan itu butuh perjuangan dan keikhlasan. Maka dari itu orang-orang yang mampu melakukannya adalhorang hebat dan Allah akan mengangkat kemuliaanya. Istilah dalam buku Gapleh "Gaul Tapi Soleb” yaitu Maidah (maaf itu indah) seindah ajaran Islam.

Akhlak berkenaan dengan cara seseorang bertindak sehingga ia dapat mengukur dan diukur moralitasnya. Norma-norma keislaman ditentukan oleh pola-pola perilaku yang disebut akhlak" (Muhyiddin, 2002: 182).

Salah satu tugas pokok dari Rasulullah adalah membawa mission sacre (amanah suci) berupaya menyempurnakan akhlak yang mulia bagi manusia (innama bu'istu li utammi makaarimal akhlak). Akhlak yang dimaksudkan ini tidak lain adalah Alquranul Karim itu sendiri, sebab hanya kepada Alquran sajalah setiap pribadi muslim itu berpedoman" (Tasmara, 1997:47).

\section{PENUTUP}

Berdasarkan hasil pengamatan dan analisis pesan dakwah pada buku Gapleh "Gaul Tapi Soleb" karya Ustadz Evie Effendie, yang telah peneliti pilah menjadi tiga bagian pesan, akidah meliputi nilai-nilai keimanan, akhlak meliputi nilai-nilai perilaku, dan syariah meliputi nilai-nilai peribadahan.

Dalam buku Gapleh "Gaul Tapi Soleb" terdapat enam password (singkatan) yang membahas mengenai akidah, setelah di analisis maka menjadi beberapa bagian pembahasan dari ke enam password (singkatan), yaitu pembahasannya meliputi ajakan beriman kepada Alquran, kemudian mengajak untuk senantiasa selalu doa atau memohon kepada Allah, dzikir, kemudian menjelaskan tentang cara untuk melakukan hijrah (perubahan dari yang jelek ke jalan yang baik) dan yang terakhir menjelaskan tentang bahaya syirik.

Dalam buku Gapleh “Gaul Tapi Soleh” terdapat enam password (singkatan) yang membahas mengenai akhlak. Pembahasan pertamanya yaitu menjelasakan tentang bagaimana cara bersosialisai (bergaul), atau bermasyarakat, mengajarkan tentang menjauhi zina, ikhtiar, ikhlas, dan tawakal. Kemudian bagaimana senatiasa bias menjaga hati dari berbagai penyakit hati, kemudian menjelaskan tentang taubat, jujur, berbakti kepada orang tua, menjaga lisan, dan cara menghadapi budaya asing yang masuk ke Indonesia.

Dalam buku Gapleh "Gaul Tapi Soleb" terdapat tujuh password (singkatan) yang membahas mengenai syariah, setelah di uraikan maka terbagi menjadi beberapa pemabahasan yaitu membahas tentang, salat, kewajiban berhijab, memakmurkan masjid, keharusan untuk zakat, infak, sedekah dan cara memanfaatkan waktu.

Dalam buku Gapleb "Gaul Tapi Soleb” dengan melakukan analisi ini penulis ingin mengemukakan rekomendasi yang mudah mudahan bermanfaat untuk kita semua, sebagai upaya perbaikan dan penyempurnaan. 
Kepada pihak Universitas Islam Negeri Sunan Gunung Djati Bandung, semoga dapat mengembangkan dan menjaga hasil penelitian para mahasiswamahasiswi jenjang sarjana berupa skripsi yang ada diperpustakaan Universitas Islam Negeri Sunan Gunung Djati Bandung dan yang ada diperpustakaan fakultas Dakwah dan Komunikasi.

Kepada Fakultas Dakwah dan Komukasi untuk lebih melengkapi sarana dan prasarana yang ada dilingkungan fakultas, seperti melengkapi buku-buku yang ada di perpustakaan fakultas, dan mengoptimalkan fasilitas yang sudah ada. Kepada jurusan Komunikasi Penyiaran Islam sebagai prodi di fakultas Dakwah dan Komunikasi yang fokus dalam Penyiaran Islam untuk lebih mengarahkan lagi mahasiswa-mahasiswi untuk mempelajari tentang penyiaran islam, dengan ditambahnya berbagai macam praktikum yang tidak sekedar materi, dan disarankan untuk memberikan pembelajaran dan pengkajian lebih mendalam tentang penyiaran Islam dengan menggunakan media yang berhubungan dengan penyiaran Islam.

Kepada Ustadz Evie Effendie sebagai seorang dai yang sedang popular baik di kalangan pemuda dan semua umur, juga mulai menggunakan buku sebgai media dakwah agar lebih selalu memberikan pesan-pesan dakwah yang bermanfaat untuk semua jamaah yang suka membaca. semoga pesan-pesan dakwah yang disampaikan bermanfaat dan hasil bacannya menjadi kepribadian dalam kehidupan sehari-hari.

\section{DAFTAR PUSTAKA}

Aliyudin, \& AS, E. (2009). Dasar-Dasar Ilmu Dakwah. Bandung: Tim Widya Padjadjaran.

Aliyudin, A. (2014). Prinsip-prinsip Metode Dakwah menurut Al-Qur'an. Ilmu Dakwah: Academic Journal for Homiletic Studies, 5(15), 1007-1022. doi:https:// doi.org/10.15575/idajhs.v5i15.431

Aripudin, A. (2014). Kajian Dakwah Multiperspektif. Bandung: PT. Remaja Rosdakarya.

Kafie, Jamaluddin. (1993). Psikologi Dakwah. Surabaya: Indah

Kasman, S. (2004). Jurnalisme Universal: Menelusuri Prinsip-prinsip Da'wab bil Qolam dalam Al Quran. Jakarta: Teraju.

Liliweri, Alo,. (1991). Memahami Peran Komunikasi Massa Dalam Masyarakat. Bandung: PT Citra Aditya Bakti.

Muhyiddin, Asep. Agus, Ahmad Safie, (2002). Metode Pengembangan Dakwah. Bandung: Pustaka Setia

Mulyana, D. (2001). Ilmu Komunikasi Suatu Pengantar. Bandung: Remaja 
A Saepulloh, T Fachruddin, Yuliani

Rosdakarya.

Mulyana, Deddy. (2007). Ilmu Komunikasi: Suatu Pengantar. Bandung: Remaja Rosdakarya

Sambas, Syukriadi. (2004). Komunikasi Penyiaran Islam. Bandung : Benang Merah Press

Saputra, W. (2011). Pengantar Ilmu Dakwah. Jakarta: Rajagrafindo Persada.

Subrayogo, I. (2001). Metodologi Penelitian Sosial-Agama. Bandung: Remaja Rosda Karya.

Tasmara, Toto. 1997. Komunikasi Dakwah. Jakarta: Gaya Media Pratama 